\title{
STUDENT'S METACOGNITION: Do INTRAPERSONAL INTELLIGENT MAKE ANY DiFFERENCE?
}

\author{
Nur Rokhima ${ }^{1}$ and Harina Fitriyani ${ }^{2}$ \\ ${ }^{1}$ Universitas Ahmad Dahlan \\ Jl. Pramuka 42 Sidikan, Yogyakarta, Indonesia \\ nur1708050022@webmail.uad.ac.id \\ ${ }^{2}$ Universitas Ahmad Dahlan \\ Jl. Pramuka 42 Sidikan, Yogyakarta, Indonesia \\ harina.fitriyani@pmat.uad.ac.id
}

\begin{abstract}
Abstrak
Metakognisi adalah kesadaran seseorang tentang proses berpikirnya untuk merencanakan, mengamati, dan mengevaluasi. Selain itu, kecerdasan siswa memiliki peran penting untuk menyelesaikan masalah. Tujuan dari penelitian ini adalah untuk mengetahui proses metakognitif siswa dalam rangka menyelesaikan masalah matematika yang ditinjau dari kecerdasan intrapersonal mereka. Penelitian ini menggunakan pendekatan deskriptif kualitatif. Subyek ini terdiri dari tiga jenis siswa yang memiliki kecerdasan intrapersonal tinggi, rata-rata, dan rendah. Instrumen yang digunakan adalah kuesioner, tes pemecahan masalah matematika (TPMM) dan wawancara. Hasil penelitian menunjukkan bahwa subjek yang memiliki kecerdasan intrapersonal tinggi dalam menyelesaikan masalah matematika melakukan perencanaan, pengamatan, dan evaluasi kegiatan di setiap tahap polya. Subyek intelijen interpersonal rata-rata berada di tahap memahami masalah, mengatur dan menerapkan rencana pemecahan masalah. Mereka telah melakukan semua kegiatan metakognitif, tetapi tidak melakukan perencanaan, mengamati, dan mengevaluasi kegiatan di tahap crosschecking. Subjek kecerdasan intrapersonal rendah berada di tahap memahami masalah, perencanaan, pengamatan, dan evaluasi. Namun, dalam mengatur penyelesaian masalah, mereka hanya melakukan perencanaan dan pengamatan tanpa mengevaluasi. Dalam tahap menerapkan rencana pemecahan masalah, mereka hanya melakukan perencanaan tanpa mengamati dan mengevaluasi.

Kata Kunci: Metakognisi, Pemecahan Masalah Matematis, Kecerdasan Intrapersonal
\end{abstract}

\begin{abstract}
Metacognition is the awareness of someone about his thinking process to plan, observe, and evaluate. Besides, the student's intelligence has an important role to accomplish the problem. The objective of this research is to know the students' metacognitive process to accomplish mathematic problem reviewed from their intrapersonal intelligence. This research used descriptive qualitative approach. The subject consists of three kinds of students who have high, average, and low intrapersonal intelligence. The instruments are a questionnaire, mathematics problem-solving test (TPMM) and interview. The result showed that the subject who has high intrapersonal intelligence in accomplishing the mathematics problem did planning, observing, and evaluating activities in every Polya stage. The average interpersonal intelligence subject was in the stage of understanding the problem, arranging and implementing the problem-solving plan. They had done all metacognitive activities but did not do planning, observing, and evaluating activities in the crosschecking stage. The low intrapersonal intelligence subject was in the stage of understanding the problem, planning, observing, and evaluating. However, in arranging the problem solving, they only did the planning and observing without evaluating. In the stage of implementing the problem-solving plan, they only did the planning without observing and evaluating.

Keyword: Metacognition, Mathematics Problem Solving, Intrapersonal Intelligence
\end{abstract}




\section{INTRODUCTION}

Garofalo and Lester in Shadiq, Fadjar (2013) who are a famous expert in Mathematics education from the United States of America have shown the importance of metacognition. They stated, "there is also growing support for the view that purely cognitive analyses of mathematical performance are inadequate because they overlook metacognitive actions." It means it is less adequate if we only use cognitive analysis in solving the mathematics problems because of the less attention of procedure related to metacognition. Thus, it shows metacognition has an essential role in the learning process uniquely associated with problem-solving. By using metacognition, the students can know the strategies used and the obstacles faced when accomplishing the problem. This can minimize the students' mistake so that they can arrange the best approaches to solve the problem.

Besides being influenced by metacognition, the student's problemsolving ability also affects the student's success in accomplishing the mathematics problem. Polya (1973) defines problemsolving as a very high intellectual activity because the student must be able to solve the problem by using the rules learned to make the problem formulation through steps; understanding the problem, developing a plan of completion, implementing a settlement plan and rechecking. Afriansyah (2016) said that problem solving ability is a mathematical ability that students need to possess. Yeo (2004) explains that solving a problem depends on five factors, including the details, skills, knowledge or concepts, metacognition process, and deeds. Latifah (2010) states that students choose a strategy, monitor the learning process, correct the error, analyze the effectiveness of learning, then those activities that require metacognition ability.

Several studies related to the student's metacognition process in mathematical problem solving have been done. Among them are Purnomo et al (2017) that high ability students are in complete and order of their characteristic of metacognition process, middle ability students are in complete and disorder of their characteristic of metacognition process, while low ability students are in incomplete of their characteristic of metacognition process. These studies are generally focused only on the process and characteristics of student's metacognition in solving mathematical problems. However, this ability is related to the students' intelligence. Intelligence is the intellectual ability that suppresses the logic in accomplishing the problem. In this research, the intelligence observed is interpersonal intelligence. The reason why focusing on this intelligence is that it is related to the attitude. It matches with KTSP or Kurikulum 2013 that focuses on the character development or position. Also, 8th graders of SMP Muhammadiyah 1 Kalasan have never performed tests 
related to their interpersonal intelligence. Interpersonal intelligence is the intelligence to understand oneself, and knowing the weaknesses. So they can motivate themselves.

Livingstone

defines

metacognition as thinking about thinking which means metacognition is a person's thinking ability that happens on themselves. Matlin (1998) states that metacognition is the knowledge, awareness, and control of the cognitive processes that occur in our self. William Peirce defines metacognition in general and in particular. According to Peirce (2003), metacognition is thinking about thinking. While Kafoussi (2013) states metacognition is the ability of a person to observe and control himself/herself against a problem known. During the mathematics learning, the most important is the students' metacognition process in solving problems related to mathematics. According to Suherman (2001), metacognition is an ability to realize what students know about themselves as learners, so that he can control and adapt his behavior optimally.

Flavell (in Haryani, 2012) mentions the reasons for the necessity of developing metacognitive abilities, among others: (1) students' thinking is sometimes wrong and tends to be different, and in this circumstance it requires good selfmonitoring and regulation, (2) students must be able to communicate, explain and provide clear reasons for their thinking to other students as well as to themselves,
(3) to survive and succeed well, students need to plan what they will do and critically evaluate other plans; (4) if students must make a tough decision, it will require metacognition skills.

Based on several definitions, metacognition is the ability awareness of someone to learn how should be determined which includes the planning process, monitoring and evaluating.

Foong and Ee (2002) argue that teaching through the giving of problems provides an opportunity for students to build mathematical concepts and develop their math skills. To solve the problem, students should observe, connect, ask questions, find reasons and draw conclusions. Success in solving problems is closely related to the student's thinking process and his metacognitive ability level. Flavell, as quoted by Livingstone (1997), states that metacognition consists of metacognition knowledge and metacognition experience/regulation. Flavell further divides metacognition knowledge into three variables, namely: (1) individual variables, referring to the knowledge of people, human (self as well as others) have limitations in the amount of information that can be processed, (2) task variables, about tasks that contain knowledge that some conditions often lead to a person being more difficult or easier in solving a problem or completing a task and (3) strategy variables, including knowledge of strategies and knowledge of how to do something or how to overcome difficulties. 
While Woolfok (2008) in Ahmad Rofli et al. (2018) describes in detail about the metacognition experience of the three processes in metacognition strategies as follows: (1) the planning process, is a decision about how much time spent in solving the problem, what strategy will be used, what sources need to be collected, how to start, and which to follow or not to do first, (2) the monitoring process, is a direct awareness of how we perform a cognitive activity. The monitoring process requires questions such as: does this give meaning? Can I do it faster? (3) The evaluation process contains decisionmaking about the process generated based on the results of thought and learning. For example, can I change the strategy that I use? Do I need help? In this study, researchers focused on studying the characteristics of students' metacognition process which will be investigated from the process of planning, monitoring, and evaluation at each step of problemsolving.

According to Laurens, Theresia (2009) level of metacognition is a level of consciousness think that shows the hierarchical students' metacognition in solving problems. As for the students' metacognition level solving mathematical problems that valid and reliable by Laurens, Theresia (2009) formulated as follows:

1. Study Tacit Use: Students use their thoughts in complete but tend not to think about the decision made in the process of figuring to do. This level indicator is: give explanations or answers erratic (merely responding). Did not know that what is said is not significant, it is not aware of any mistakes or weaknesses, resolve the problem by try - try, do not understand what is not known, give inconsistent answers, have a disadvantage in mastering the material and analyze the problem.

2. Study Aware Use: Students use thinking to solve problems and be aware of what and why to do specific thoughts. Indicators of this level are: to reveal why and how these ideas are used, experience confusion when reading problems because they have not come across an idea of what is learned, taking a decision against the background of a particular reason, aware of the weaknesses, knowing what you do not know, to understand the problem completed, mastered the mathematical concepts that underlie the problem.

3. Study Semistrategic Use: student directs his thinking to realize there is no strategy or means used to solve the problem, as well as plans to improve the precision of his thought. Indicator an indicator of this level is: try to check on what she thought, realizing what he thinks is not right (be aware there is an error) but cannot decide how to fix the mistake, initially showed skepticism toward what he thinks, but after being given the help they believe the truth of thinking to do. 
4. Study Strategic Use: Students can organize their thoughts, consciously using specific strategies that improve the precision of his thinking. Indicator an indicator at this level is: aware of their ability, generally knows what he's doing, demonstrated in maintaining the arguments that support the precision of thinking, experimenting, checking through the calculations and revise, compare or match the result of the settlement with the information that is known, has how to convince what is made to have the ability to master mathematical concepts related to the given problem, believing what he was doing.

5. Study Semi-reflective Use: Students reflect this thinking but not necessarily at every step of solving problems created. This level indicator is: aware of their ability; conduct reflection does during the process of finding the answers, explain the issue thoroughly and then examine and rethink his work, tend to match or prove the final answer, demonstrating the ability to master the concepts underlying the mathematical problem.

6. Use Reflective Study: Students can reflect on their thinking either before, after and during the process and think about how to proceed and how to improve. This level indicator is: always check every step and immediately make revisions using various strategies to demonstrate or improve the precision of his thinking, analyzing problems before the finish, understand and master the mathematical concepts that underlie a given problem.

Armstrong, (2000) Intrapersonal intelligence is also known as "self-smart" whereby individuals who possess intrapersonal intelligence can understand their feelings, emotions, and needs. Dummett (2006) They are also able to follow their inner feelings and are capable of doing self-reflection. They can concentrate and make reasoning, know themselves well in many aspects of attitudes, intentions, goals in life, and selfmotivation, but sometimes they like to be alone. According to Kornhaber, Fierros and Veenema (2004) in Nurulwahida, and Aizan (2016), the application of interpersonal and intrapersonal intelligence in life can foster efficiency to master the critical thinking discipline. Through individual intrapersonal intelligence, an individual can identify him/herself by understanding the purposes, goals, and will of his or her life. On the other hand, through intrapersonal intelligence one can identify oneself by following one's own needs, aspirations and requirements.

Sellars, Maura (2008) Gardner's changing perceptions of intrapersonal intelligence; which he nominates as the most important construct for twenty-first century learners; are explored, as is the degree of accuracy with which Gardner's definitions are translated into popular texts to guide teachers in the implementation of Multiple Intelligences 
Theory in their classrooms in order to promote more successful learning outcomes for their students. Sellars, Maura (2006) These results suggest that strong, accurate intrapersonal intelligence may underpin all the other aspects of self, including the knowledge and skills needed to develop self-directed learning.

Intrapersonal intelligence is an intelligence that one has in recognizing oneself, a person who has intrapersonal intelligence they can motivate themselves and know the advantages and weaknesses they have; even they have the independence and strong confidence to achieve goals.

\section{Methodology}

This research used the descriptive qualitative approach. It showed the broad and detailed overview related to the grade 8 student of SMP Muhammadiyah 1
Kalasan in accomplishing mathematic problems which have high, average, and low intrapersonal intelligence. The research had done in SMP Muhammadiyah 1 Kalasan on the even academic year of 2016/2017. The subjects are the grade 8 students of SMP Muhammadiyah 1 Kalasan who have intrapersonal intelligence based on its level. To determine the issue, they were given a questionnaire consisted of 40 questions. Based on the questionnaire result, then categorized into three categories: high, average, and low intrapersonal intelligence. In collecting the data of intrapersonal intelligence, the researcher uses data collection, mathematics problem-solving test, an interview. According to Sugiyono (2015: 307), he says "instrumen utama dalam penelitian kualitatif adalah peneliti sendiri."

Table 1.

The Outline of Problem Solving Test

\begin{tabular}{|c|c|c|c|c|}
\hline $\begin{array}{c}\text { Stand ard } \\
\text { Competence }\end{array}$ & $\begin{array}{c}\text { Basic } \\
\text { Competence }\end{array}$ & Indicators & $\begin{array}{c}\text { Metacog nitive } \\
\text { Skills }\end{array}$ & $\begin{array}{c}\text { Question's } \\
\text { Number }\end{array}$ \\
\hline \multirow[t]{2}{*}{$\begin{array}{l}\text { Determining } \\
\text { the } \\
\text { measurement } \\
\text { section of } \\
\text { circle and its } \\
\text { dimension }\end{array}$} & \multirow[t]{2}{*}{$\begin{array}{l}\text { Determine } \\
\text { the } \\
\text { measurement } \\
\text { and section } \\
\text { of circle }\end{array}$} & $\begin{array}{l}\text { Given the } \\
\text { measurement } \\
\text { of radius of } \\
\text { two } \text { big } \\
\text { tangent circles } \\
\text { and a small } \\
\text { circle placed } \\
\text { between them. } \\
\text { The students } \\
\text { can determine } \\
\text { the radius of } \\
\text { the small } \\
\text { circle's length. }\end{array}$ & \multirow[t]{2}{*}{$\begin{array}{l}\text { Planning, } \\
\text { Monitoring, } \\
\text { Evaluating }\end{array}$} & 1 \\
\hline & & $\begin{array}{l}\text { Given the } \\
\text { diameter of a } \\
\text { plant that will } \\
\text { be fixed The } \\
\text { students can } \\
\text { determine the } \\
\text { cost of paving } \\
\text { installation. } \\
\end{array}$ & & 2 \\
\hline
\end{tabular}


According to Chairani, Zahra (2016:102), the interview guidelines referring to the metacognitive (metacognitive skills) is as follows:

Table 2.

Interview Guidelines

\begin{tabular}{|c|c|}
\hline & $\begin{array}{l}\text { Metacog nitive Process } \\
\text { (Metacognitive Skills) }\end{array}$ \\
\hline & $\begin{array}{l}\text { How do you comprehend the } \\
\text { problem? } \\
\text { Can you explain why you use that } \\
\text { strategy to comprehend the } \\
\text { problem? } \\
\text { How do you identify the data } \\
\text { when comprehending the } \\
\text { problem? } \\
\text { If it does not work, why don't you } \\
\text { use another way? If it does, } \\
\text { please explain that way. }\end{array}$ \\
\hline & $\begin{array}{l}\text { Give me the reason why those } \\
\text { reasons are chosen } \\
\text { Why are you so confident that } \\
\text { your plans are appropriate to } \\
\text { use? } \\
\text { What knowedge or information } \\
\text { that you need to make the } \\
\text { completion of plan? }\end{array}$ \\
\hline & $\begin{array}{l}\text { Why do you assume this } \\
\text { completion fits to your plan? } \\
\text { (Questions related to the written } \\
\text { problem solving steps which } \\
\text { emphasize on words such as } \\
\text { "how", why, give me your reason, } \\
\text { and explain.) }\end{array}$ \\
\hline & $\begin{array}{l}\text { How do you know that what you } \\
\text { have done is correct? } \\
\text { How is your plan to crosscheck } \\
\text { the result? } \\
\text { If there is, please explain it. If } \\
\text { there is no plan, explain it? }\end{array}$ \\
\hline
\end{tabular}

The instrument validity in this research uses construct validity. The judgment expert can be used to examine the construct validity. An expert lecturer does this validation. According to Miles and Huberman (2004:16-20), the activity in analyzing the data are data reduction, data display, and conclusion drawing/verification.

\section{Results And Discussion}

Based on the result of intrapersonal intelligent questionnaire of grade VIII SMP
Muhammadiyah 1 Kalasan, the students' propensity of intrapersonal intelligent classification are as follows:

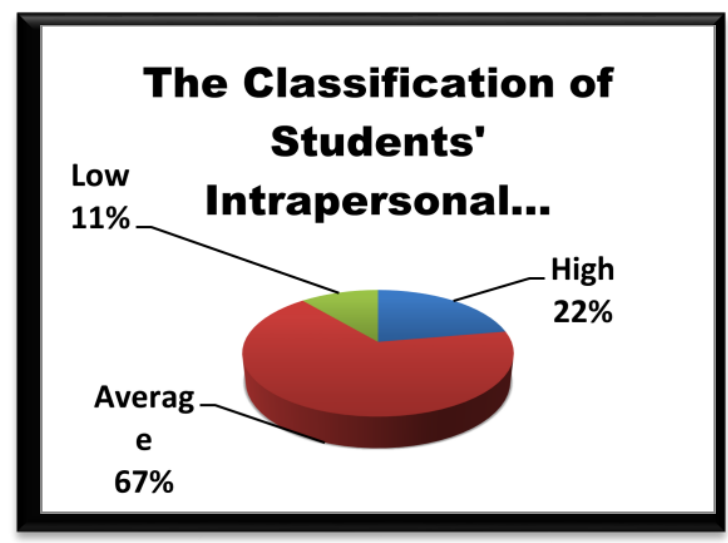

Figure 1. The Classification of Students Intrapersonal Intelligence

Based on figure 1 above, it shows the average intrapersonal intelligence is dominant. It matches with Efendi, Fitri Mares research (2015) that most grade 4 students of SD in Gugus I districts Srandakan belong to average intrapersonal intelligence.

Furthermore, the researcher took one subject from each kind of intrapersonal intelligence. Thus, it is based on the teacher's suggestion. It is related to the equal mathematics ability and communicative ability through writing or oral. After that, those subjects were given two questions in essay form of a problemsolving test. Those had to be done in 40 minutes. After finishing the test, one by one, the subject was interviewed to find out detailed information about the student's metacognition in accomplishing the mathematics problem. All activities 
done by the subjects during the interview were recorded using the camera.

Based on the result explained previously, the score of metacognitive skills (TPMM) is as follows:

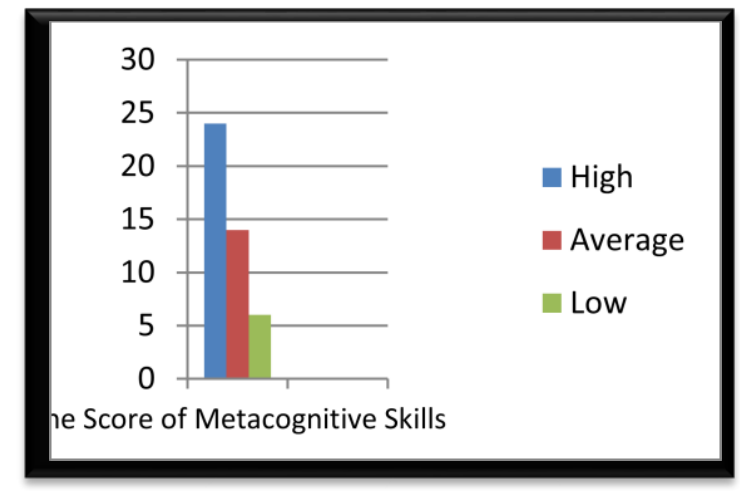

Figure 2. The Score of Metacognitive Skills (TPMM)

Here is a brief metacognitive profile of grade 8 students of SMP Muhammadiyah 1 Kalasan in accomplishing mathematic problems:

1. High intrapersonal intelligent subject

Metacognition Skills: In accomplishing the mathematics problem, the subject did all metacognitive activities such as developing the plan, observing the implementation, and evaluating the action in every Polya stage of problem-solving.

Metacognition Knowledge: Subject can understand the problem. The subject can plan the strategy to accomplish the problem. The subject can realize the concept and the calculation method used.

The subject can do an evaluation.

Level: Reflective Use

\section{Average intrapersonal intelligent subject}

Metacognition Skills: In accomplishing the mathematics problem, the subject did not do all metacognitive activities such as in the stage of crosschecking the problem. The subject only did a maximal metacognitive activity in the step of understanding the problem, arranging the problem-solving plan, and applying the problem-solving procedure.

Metacognition Knowledge: Subject can understand the problem. The subject can plan the strategy to accomplish the problem. The subject is quite capable of realizing the concept and the calculation method used. The subject is quite capable of doing an evaluation.

\section{Level: Strategic Use}

3. Low intrapersonal intelligent subject

Metacognition Skills: In accomplishing the mathematics problem, the subject did all metacognitive activities in the stage of understanding the problem. In the step of arranging the problem-solving plan, the subject only did the planning and observing without evaluating. When applying the problem-solving plan, the subject just did planning without seeing and evaluating. Besides, the subject did not do any metacognitive activities in the stage of crosschecking.

Metacognition Knowledge: Subject is less capable of planning the strategy to accomplish the problem. The subject is less capable of realizing the concept and the calculation method used. The subject is less capable to do an evaluation.

Level: Tactic Use

Thus, it shows there is a different metacognitive activity done by the high, average, and low intrapersonal intelligent 
subjects in accomplishing mathematic problem based on the stage of Polya problem-solving. A top intrapersonal brilliant topic is in the level of reflective use. An average intrapersonal intelligent subject is in the level of strategic purpose. A low ordinary intrapersonal intelligent subject is in the level of tactic use. This means there is a different intrapersonal intelligent category that causes on what metacognitive level they belong to. The intrapersonal smart type is directly proportional to the level of metacognition. It implies the high intrapersonal intelligent subject has a higher level of an intrapersonal class than the others. The research done by Parju Khoirul Rohmah Safitri (2014) supports that, that highability learners have reflective use metacognition, medium ability to have metacognitive strategy use, low capacity to have metacognition of aware use and tacit use.

\section{CONCLUSION}

The high intrapersonal intelligent student in accomplishing the mathematics problems did all metacognitive activities such as developing the plan, observing the implementation, and evaluating the action in every stage of Polya problem-solving. If reviewed from the metacognitive level, they belong to reflective use category. The average intrapersonal intelligent student in accomplishing the mathematics issues did not apply to all metacognitive activities, for example crosschecking the problem they have got. They did a maximal metacognitive activity in the stage of understanding the problem, arranging the problem solving, and applying the problem-solving plan. If reviewed at the metacognitive level, they belong to strategic use category. The low intrapersonal intelligent student in accomplishing the mathematics difficulties did all metacognitive activity in the stage of understanding the problem. In the step of arranging the problem solving, they only did metacognitive activities such as planning and observing without evaluating. When applying the problemsolving plan, they just did planning metacognitive activity without seeing and evaluating. Meanwhile, they did do any metacognitive activity in the crosschecking stage. If reviewed from the metacognitive level, they belong to tactic use category.

\section{DAFTAR PUSTAKa}

Afriansyah, E. A. (2016). Investigasi Kemampuan Problem Solving dan Problem Posing Matematis Mahasiswa via Pendekatan Realistic. Mosharafa: Jurnal Pendidikan Matematika, 5(3), 269-280.

Ahmad Rofli, et al. (2018). Characteristics of Student's Metacognition Process at Informal Deduction Thingking Level In Geometry Problems. International Journal on Emerging Mathematics Education, 2(1), 88-104.

Armstrong, T. (2000). Multiple intelligences in the classroom. Virginia, USA: Association of Supervision and Curriculum Development. 
Chairani, Zahra. 2016. Metakognisi Siswa dalam Pemecahan Masalah Matematika. Yogyakarta: Deepublish.

Dummett, C. W. (2006). Successful pedagogies for an Australian multicultural classroom. International Education Journal, 7(5), 778-789.

Efendi, Fitri Mares. 2015. Hubungan antara Kecerdasan Intrapersonal dengan Prestasi Belajar Siswa Kelas IV SD se-Gugus I Kecamatan Srandakan Bantul Yogyakarta Tahun Ajaran 2014/2015. Retrieved from http://eprints.uny.ac.id/26468/ on November 19, 2016.

Foong, P.Y. \& Ee, J. (2002). Enhancing the learning of underachievers in mathematics. ASCD Review, 11(2), 2535.

Kafoussi, S. (2013). Elementary Students' Spontaneous Metacognitive Function Different Type of Mathematical Problems. Journal Research in Mathematics Education (Online), 2(2), 242-267.

Latifah L.N. (2010). Pengaruh Model Pembelajaran Kooperatif Tipe Co-Op Co-Op terhadap Peningkatan Berpikir Kritis dan Ketuntasan Belajar Matematika Siswa SMA Bandung. Doctoral Dissertation. Bandung: UPI.

Laurens, Theresia. 2009. Penjenjangan Metakognisi Siswa. Disertasi. Program Pascasarjana Universitas Negeri Surabaya.

Livingstone, J.L. (1997). Metacognition: An Overview (On Line), Retrieved from http://www.gse.buffalo.edu/fas
Matlin, M. (1998). Cognition. Philadelphia: Harcourt Brace College Publisher.

Miles and Huberman. (2014). Analisis Data Kualitatif Buku Sumber Tentang Metode - Metode Baru. Jakarta: UIPress.

Nurulwahida and Aizan. (2016). Enriching Orphans' Potentials through Interpersonal and Intrapersonal Intelligence Enrichment Activities. International Journal of Instruction. 9(1) January 2016

Pajru, Khoirul R.S. (2014). Metakognisi Peserta Didik Dalam Memecahkan Masalah Matematika di Kelas XI SMA NU 01 Al Hidayah Kendal. Retrieved from

http://eprints.walisongo.ac.id/4192/ on November 19, 2016

Pierce, W. (2003). Metacognition: Study strategies, monitoring and motivating. A workshop paper presented at Prince George's Community College. Retrieved from http://academic.pg.cc.md.us//

Polya. (1973). How to solve it. New Jersey: Princeton University Press.

Purnomo, D., Nusantara, T., Subanji, \& Rahardjo, S. (2017). The Characteristic of the Process of Students' Metacognition in Solving Calculus Problems. International Education Studies, 10(5), 13-25.

Sellars, Maura. (2006). The Role Of Intrapersonal Intellegence in self Directed Learning. Issues In Educational Research, Vol 16. 2006. 
Sellars, Maura. (2008). Intelligence for the 21st Century: A Discussion of Intrapersonal and Emotional Intelligences. International Journal of Learning, 15(2), 79-87.

Suherman, E. (2001). Strategi Pembelajaran Matematika Kontemporer. Bandung: JICAUniversitas Pendidikan Indonesia.

Yeo, J.K.K. (2004). An exploratory study of secondary two students' mathematics anxiety and mathematical problem solving. Doctoral Dissertation. Singapore: National Institute of Education.

\section{Author's CURRiculum VitAE}

\section{Nur Rokhima, S.Pd.}

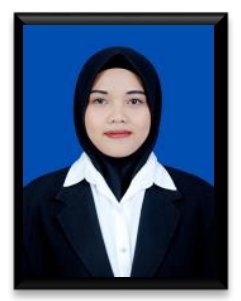

Born in Sleman, 10 December 1994. Study: S1 mathematics education in UAD graduated in 2017, now S2 Mathematics education in UAD. At 2017, She publication at UNIMUS national seminar.

\section{Harina Fitriyani, M.Pd.}

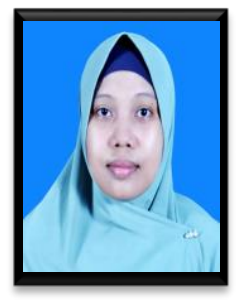

Born in Banyuwangi, 4 Juli 1984. She is Lecturer in the mathematics education study program at UAD. Study: S1 mathematics education in UAD graduated in 2006, S2 Mathematics education in UNESA graduated in 2011. At 2016 and 2018, she got a research grant "Penelitian Dosen Pemula" from Ristekdikti with the title respectively "Proses berpikir matematis rigor (rigorous mathematical thinking) mahasiswa ditinjau dari gaya kognitif" and "pengembangan alat geoklik Untuk mendukung kegiatan pembelajaran geometri". She participated in several national seminars and international conferences as a presenter in parallel sessions such as "World Association of Lesson Studies (WALS) International Conference" in UPI Bandung at 2014. She also participated in "The 8th International conference on Lesson Study (8th ICLS)" in Universitas Hamzanwadi Lombok Timur at 2017 and "The 1st Ahmad Dahlan International Conference on mathematics and mathematics education (ADINTERCOMME)" in UAD at 2017 (Proceeding indexed by Scopus). 
This page is intentionally left blank 